\title{
Attitudes of Mayors Toward Tourism In Rural Areas: The Case Of The Turkish Rural Municipalities
}

\author{
Nurettin Ayaz ${ }^{A}$, Yüksel Öztürk ${ }^{B}$ \\ Received: February 2016 | Accepted: October 2016 \\ DOI: 10.18421/TRZ20.03-04
}

\begin{abstract}
It is essential that attitudes of stakeholders towards tourism be examined in today's extreme competition among the destinations. It is further essential to carefully analyze the stakeholders of destinations, which are going to be developed in rural areas and which plan to have a share in tourism gains. The objective of this study is to present the relationship between the attitudes of mayors towards tourism and tourism activities of rural municipalities during the participation of the stakeholders in rural areas which are selected as areas for alternative tourism development. To this end, two-phase research process is followed where, in the first phase, secondary sources are thoroughly examined and where, in the second phase, the relationship between the attitudes of mayors towards tourism and the activities of municipalities in rural areas is analyzed by the means of questionnaires conducted to the mayors. In the end of the research process, an intermediate relationship is identified between the attitudes of mayors towards tourism and the activities of municipalities towards tourism. In the context of research findings, certain suggestions are accordingly presented which might improve the mayors on tourism patterns and which might increase the level of participation of rural area municipalities in tourism.
\end{abstract}

Key words: Rural area tourism, stakeholder analysis, mayors, mayor's attitude, Turkey.

\section{Introduction}

The economic potential of tourism to decrease the poverty in rural areas has recently become much more evident and the efforts to improve the legal and political framework to diversify the economies of the rural areas have gained speed (Hall, Jenkins, 1998; United Nations, 2007; Zecevic, 2011). Tourism is started to be seen as an important tool for development (Long, Lane, 20oo; Farrell, Russell, 2011; Ertuna, et al., 2012) as tourism is a potential opportunity in terms of being a significant input and bringing dynamism to local economies; preventing migration from countryside to cities; increasing female employment; improving the entrepreneurial spirit among the

\footnotetext{
Karabük University, Faculty of Tourism, Karabük, Turkey; ayaznurettin@yahoo.com

Gazi University, Faculty Tourism Gölbaşı-Ankara, Turkey; oyuksel@gazi.edu.tr

Corresponding author: yukselozturk66@gmail.com
} 
local populace; decreasing the development gap among the regions; increasing the possibilities to better market for the agricultural products of the local populace; encouraging the interaction between the rural and urban population; implanting a stronger sense of ownership of the land in the rural populace; contributing to the improvement of life quality in the countryside and in terms of reservation of the historical buildings in rural area and bringing back the traditional activities to life such as village festivals (Oppermann, 1996; Sharpley, Sharpley, 1997; Hall, 1998; Smith, Krannich, 1998; Lewis, 1998; Campbell, 1999; Sharpley, 20oo; Momsen, 20oo; Lesley, Hall, 2001; Kokkranikal, Baum, 2002; Ribeiro, Marques, 2002; Holland, et al., 2003).

At the same time, tourism is developing at a slow pace and therefore, it is suggested that various public and private stakeholders need to be organized to make tourism, which is believed to be a source of solution for economic problems, an efficient means of development (Godfrey, 1998; Ertuna ,et al., 2012; Ayaz, 2012).

Therefore, this paper is aimed at studying the relationship between the activities of municipalities, which are accepted as an important stakeholder by rural population and are expected to play a role in the development process, and the attitudes of mayors towards tourism. More specifically, it aims to experimentally test the relationship between the tourism activities of municipalities and the attitudes of mayors towards tourism and to examine various relationships among the dimensions to be determined. Therefore, the outputs of this study are believed to help the stakeholder authorities, who are expected to participate in the tourism development at public level in rural areas. During the research, the attitudes of mayors in rural areas towards tourism are examined at two levels, namely cognitive and emotional attitudes while the tourism activities of municipalities in rural areas at four levels, namely creation of social awareness, organizational structure development, product development, and product marketing thereby the level of relationship between the attitudes of mayors in rural areas towards tourism and the tourism activities of those mayors is analyzed.

\section{Literature Review}

\section{Rural tourism}

It is believed that a high percentage like $75 \%$ of the poor population in the world live in rural areas. Particularly in developing countries, the majority of chief tourism destinations such as national parks, unspoiled natural areas, mountains, lakes, and cultural heritage areas are located in rural areas. Therefore, tourism in those rural areas is approached as a driving force for economy (Holland et al., 2003). Tourism has recently been accepted as a means to encourage the regional development, mostly in those distant to sea, mountainous, and underdeveloped regions, through its features of potential employment, income, and creating synergy in other sectors (Ribeiro, Marques, 2002). Tourism, as a strategy to level down the increasing developmental imbalance problems in rural areas (Kokkranikal, Baum, 2002), is adopted as a significant component of rural development by the rural population and the non-governmental societies which support the population (Ashley, 20oo). Furthermore, the increasing trend towards daily walks in the countryside, perception of rural areas as the true representative of natural history heritage, conception about the countryside to be source of clean air and water and open air activities, growing availability of those areas to transportation and communication, and the elimination of various political and economic barriers can be counted as the major factors which have played an important role in the growing demand for tourism in rural areas (Tchetchik, et al., 2006). 
In today's world, more people are participating then ever in rural tourism as it is gaining more ground as a fast growing sector particularly in Europe and North America. To illustrate, while in the United Kingdom, annual income obtained from rural tourism amounts to 14 billion dollars and 380,0oo people are employed in this field, in Canada, $3 \%$ of employment in tourism belongs to rural tourism. In the United States, it is reported that 90 million people traveled to the countryside in 2002-2004 (Tchetchik, et al., 2008). Furthermore, in Spain, as one of the major countries in the world in terms of tourism income, bed capacity in rural tourism, which was 46,354 in 2001, reached to 120,517 in 2008 and the number of tourism orientated accomodation facilities, which was merely 1,074 in 1994, reached to 14,442 in 2010 (Garay, et al., 2011). As of 2012, there was a bed capacity of 100,ooo for rural tourism affiliated to various professional organizations in 28 member countries of the European Union (Ayaz, 2012).

Assumptions about the rural tourism and how the rural population will realize and maintain the tourism activities have been of great concern to planners and policy makers. Especially, tourism policies and management of those policies are of major importance. However, organizational structure of rural tourism, the mismatch of rural development policies of ruling ideologies with tourism policies in general, and the variation of those policies from country to country create an important challenge to the formulation and management of tourism policies (Sharpley, 2006).

It is evident that natural resources, activities based on authentic agriculture and ecology, history, and "the attraction of a small town" do not suffice by themselves. Those factors can only turn into a local source of income only when local authorities as well as local businessmen start to deal with venues such as developing and marketing of a successful product and establishment of an adequate infrastructure. The level of knowledge that the local authorities have is of great importance to make wise business decisions (Woods, 200o). However, local authorities have so far much less participated in rural tourism for holding the idea that the "development of tourism is based on the initiatives of the private sector." Therefore, local authorities do generally have minor experience in the fields of planning, development, and management. Nevertheless, this situation has changed in recent years and there has occurred awareness about the important role to be played by the local authorities. Consequently, those areas, which have managed to diversify their products despite the similar physical conditions, have started to take a bigger share from tourism income when compared to earlier times (Kotler, Gertner, 2002).

\section{Stakeholders of rural tourism}

The main problems facing the rural tourism are the lack of knowledge by the demanders, lack of ability related to the presentation of product, and insufficient information about the market which is worked on (Mitchell, Derek, 2005). It is essential that public support to be provided first to minimize those problems and develop rural tourism. Rural population needs to be hierarchically organized to conduct plans and projects for tourism in a healthy pattern. Organization and team work are matters of importance to integrate the rural tourism into the regional, national, and international tourism (Soykan, 2004). Planning and coordination are indispensable to activate a society in general and to activate rural tourism at particular (Stynes, O'Halloran, 1987). It is generally accepted that a well-coordinated tourism is more valuable than a less coordinated one (Clark, Chabrel, 2007). Management organizations and leadership, especially in destinations where the planning, development, and the coordination of tourism is single-handedly executed, are major factors for public approach towards tourism in rural areas and for creating difference in tourism development (Wilson, et al., 2001). 
Stakeholders in destinations are key players in planning, development, and organization of tourism. Those stakeholders undertake positions of investors, planners, developers, and organizers within a sustainable development program (Timur, Getz, 2008). Therefore, to rightfully identify, organize, and manage the stakeholders is an important matter. It is vital that many various public and private stakeholders be organized for tourism, which is presented as a source of solution for economic problems in rural areas where a fast economic and social change is experienced, to become a major means of development. In this process of organization, to know the attitudes of stakeholders might make a contribution to tourism development.

In rural areas, natural and historical appeals, public protection of authentic features, tourism consciousness managed to harmonize the local cultural characteristics, transportation, accomodation, and achievement of international standards in food and beverage services, and the interest of local, regional, and national authorities in tourism constitute the factors of supply for tourism (European Commission, 1999). Local authorities are the players who can undertake roles to present those factors of supply by the means of making developmental fund, meeting the need for essential infrastructure, reconstructing, sustaining, and cleaning places which appeal to tourists, and providing the staff and enterpreneurs in tourism as well as the local population with essential training and professional assistance (Wilson, et al., 2001).

Under the motto of "think global, act local," local authorities have started to be expected to manage and improve their performances, harmonize their own sustainable objectives with activities and policies of local authorities, give weight to the efforts of awareness and education, counsel to and include the public, establish partnerships with various groups within the local population, and to track this process through measurement and reporting in the context of sustainability (Leslie, Hughes, 1997; Middleton, Hawkins, 1998).

Efforts for the improvement of rural tourism have also gained speed in Turkey. In the analysis, namely, Turkey as Tourism Destination, prepared by the SWOT through giving full consideration to the tourism trends in the world as well as in Turkey, and the Ninth Development Plan, prepared by the Turkish state, local dynamics, formation of a venue for development based on internal potential, improvement of institutional capacity at local level, acceleration of rural development, and the formation of sufficient interest in tourism by the public, primarily by the local authorities are highlighted. Provincial institutions of the central administration, local authorities, non-governmental organizations, endowments, cooperatives, unions, and universities are identified as main actors to play a role in tourism development. Among those various establishments, municipilaties, as an important subunit of local authorities, are seen as institutions which know the rural area best, therefore which have the best power to direct the rural population. Tourism and touristic activities are counted as the fundamental duties and responsibilities of municipalities in accordance to the Law No 5393 and Law No 5355 (Ayaz, 2012). Municipalities are assessed as actors to maintain the balance between protection and use in tourism regions, manage sustainability, harmonize the needs of local population and tourists, and to direct the local authorities in usage of historical monuments to the touristic ends (Azaklı, Özgür, 2004).

\section{Research hypothesis}

The chief objective of this study is to measure the relationship between the tourism activities of municipalities, seen as important stakeholders in tourism development and management, and the attitudes of mayors towards tourism. Furthermore, to support the localization process of 
public services in rural areas by the means of tourism, to present a field research based-point of view towards tourism services that are aimed to be localized in rural areas, and so to guide similar studies which would improve suggestions for rural tourism are the other objectives of the research. This study is distinct in terms of identifying the tourism activities of municipalities in rural areas from the perspectives of mayors towards tourism and emphasizing the importance of empowering of mayors in tourism.

In the present study, the hypotheses to reach the objectives counted above are defined as follows:

H1: There is a correlation between the attitudes of mayors towards tourism and the tourism activities of municipalities in rural areas.

$\mathrm{H1}_{a}$ : There is a correlation between the cognitive attitudes of mayors and the activities of municipalities to create social awareness about rural tourism.

$\mathbf{H 1}_{b}$ : There is a correlation between the cognitive attitudes of mayors towards tourism and the activities of municipalities to develop organizational structure in rural tourism.

$\mathbf{H 1}_{c}$ : There is a correlation between the cognitive attitudes of mayors and the activities of municipalities to develop products in rural tourism.

$\mathbf{H 1}_{d}$ : There is a correlation between the cognitive attitudes of mayors and the activities of municipalities to market products in rural tourism.

$\mathrm{H1}_{e}$ : There is a correlation between the emotional attitudes of mayors and the activities of municipalities to create social awareness in rural tourism.

H1: There is a correlation between the emotional attitudes of mayors and the activities of municipalities to develop organization structure in rural tourism.

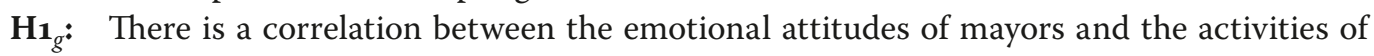
municipalities to develop products in rural tourism.

$\mathbf{H 1}_{h}$ : There is a correlation between the cognitive attitudes of mayors and the activities of municipalities to market products in rural tourism.

\section{Tourism and attitude researches}

The very first researches on attitude in tourism were based on the positive impact of tourism on local population. Later researches started to examine the tourism attitudes in the context of negative impact of tourism. Beginning from the 1980 os and 1990s, both the positive and negative impacts of tourism were examined in a more balanced and systematic pattern (Latkova, 2008). Surveys have so far indicated that "while the attitude of host society towards tourism was affirmative at the early stage of tourism development, this trend started to decline at a later stage of the tourism development (Long, et al., 1990). Furthermore, there started studies to establish a relationship between attitude surveys and social change theory. Those surveys point out that local population who benefited from tourism presented a positive attitude towards the development of tourism (Latkova, 2008).

Butler in his model, "Tourism Area Life Cycle" of 1980, asserts that significant changes might take place in course of time in the infrastructure system, marketing strategies, naturally and artificially constructed environments, and in the attitudes of local population towards tourism and adds that those changes need to be followed up.

As the literature indicates, attitude research carries special significance for tourism. Surveys on attitudes are important sources of information for a healthy tourism development in a certain area or region. Furthermore, given their features to define the case and to detect information, those surveys are significant sociological resources which might be applied in tourism 
development and which might be of use in venues of sustainable tourism, strategic planning and development, execution and supervision of programs. This study, aimed at analyzing the attitudes of mayors in rural areas, distinguishes from early studies on attitudes of local population towards tourism, such as Long, et al. (1990), Smith and Krannich (1998), Claudia and Gürsoy (2004), Ishikawa and Fukushige (2007), Wang and Pfister (2008), Latkova (2008) and Byrd, et al. (2009) mainly for its extensive research on attitudes of public stakeholders, thereby making a modest contribution to the literature in tourism.

\section{The Case Study Area and Methodology}

\section{Study areas}

Given its natural, historical, cultural, and human resources, Turkey is a country which can meet the demands in tourism at international level. General analyses indicate that tourism as a sector has been fast growing in Turkey, yet with a concentration largely in urban areas and centers with touristic appeal. The country with its each region having its own unique tourism diversity is still of much less use in the development of rural areas through tourism. It is asserted that what Turkey achieved in coastal areas in terms of tourism development and increasing tourist number could be duplicated in rural and developing areas (Tosun, et al., 2003). Therefore, Turkey aims to show the same success in rural areas as it showed in coastal regions and to turn tourism into a sustainable economic activity in accordance with the Action Plan, 20072013 under the national Tourism Strategy in Turkey for 2023.

The research field of this study is specified according to the "Tourism Strategy in Turkey 2023: Action Plan, 2007-2013" prepared by the Republic of Turkey Ministry of Culture and Tourism. Therefore, cities, shown of first priority for tourism development, namely, Afyonkarahisar, Ağrı, Amasya, Burdur, Çankırı, Çorum, Diyarbakır, Erzincan, Erzurum, Giresun, Hatay, Isparta, Kahramanmaraş, Kars, Kastamonu, Konya, Kütahya, Mardin, Nevşehir, Ordu, Samsun, Sivas, Şanlıurfa, Tokat, Trabzon, Uşak, Van, and Yozgat, are selected to be research fields.

\section{Study methods}

A two-phase study is followed in the present research. In the first phase, literature on the topic, earlier similar researches and the methods applied, and the secondary data are thoroughly examined. In this phase, research question and theoretical framework are set as well. Regarding the second phase, a scale is developed to define the attitudes of mayors towards tourism in rural areas and the tourism activities of municipalities in those areas.

In the process of preparing the questionnaire, the studies of Campanhola and Graziano da Silva (1999), Kastenholz (1999), Hegarty and Prezeborska (2005), Ishikawa and Fukushige (2007), Yüksel and Yüksel (2008), Wang and Pfister (2008), Eraqi (2010), and Strömgren and Andersson (2010) are benefited from while specifying the questions on the questionnaire. However, specific questions towards the field are prepared by the author. While preparing the questions in the research, opinions of experts (four tourism academics) are applied. Suggestions and critics of academics are utilized in the context of expert opinion.

A questionnaire of two sections is prepared to identify the attitudes of rural mayors towards tourism and the activities of rural municipalities towards tourism in rural areas. In terms of 
pretesting, 50 mayors are conducted questionnaires in the cities, namely, Amasya, Çankırı, Erzurum, Hatay, Kahramanmaraş, Konya, Mardin, Nevşehir, Ordu, Samsun, Sivas, Şanlıurfa, Tokat, Trabzon, and Van. Pretesting is subjected to factor analysis and reliability analysis. Factor analysis is made at two levels on one hand including the cognitive and emotional attitudes of mayors towards tourism and at four levels on the other including activities of municipalities towards tourism in rural areas, creating a social awareness, developing organizational structure, and developing and marketing product of tourism. In the end of the pretesting, scale is reorganized through 9 questions regarding the cognitive attitudes of mayors, 2 questions about the emotional attitudes, 3 questions about the creating social awareness, 12 questions regarding the efforts to develop a product, 2 questions regarding the product marketing, and 2 questions about the handicaps to participate in tourism. In the end of the reliability analysis, the value of Alpha (Cronbach) was defined as 0,90. Questionnaires, by the means of pollster, were conducted to mayors face to face in the period of January-August 2012.

In the region defined as research field, there are 1,390 municipalities in total. Given the spaciousness of the area as well as the maters of time and cost, sampling is applied in the research field. Sampling is determined to be 359 in accordance with the study of Ryan (1995). During the research, 500 questionnaires are spread out, while 467 of them are responded. Therefore, the rate for response to questionnaire is identified as $93,4 \%$ and the research is carried out over those 460 questionnaires.

\section{Data analysis}

Data, collected through the questionnaires conducted during the research, is uploaded to computer and so the database is formed. Reliability and factor analyses regarding the database are subsequently held. Kasier-Meyer-Olkin (KMO) coefficient, the results of Barlett's test, the results of factor analysis, and the reliability coefficient for each factor, all which are applied to examine the relevance of data to define the attitudes of mayors towards tourism and the activities of municipalities towards tourism in rural areas, are presented in Table 1 and Table 2:

Table 1. Factor Analysis for the Attitudes of Mayors towards Tourism

\begin{tabular}{|c|c|c|c|c|c|}
\hline Factor & Mean & $\begin{array}{l}\text { Standard } \\
\text { Deviation }\end{array}$ & $\begin{array}{l}\text { Factor } \\
\text { Loading }\end{array}$ & $\begin{array}{l}\text { Cronbach } \\
\text { Alpha }\end{array}$ & $\begin{array}{c}\text { Variance } \\
\text { Explained (\%) }\end{array}$ \\
\hline \multicolumn{4}{|l|}{ Cognitive Attitudes Towards Tourism $(n=460)$} & 0.918 & 34.553 \\
\hline $\begin{array}{l}\text { Tourism increases the employment opportunities } \\
\text { for the local population. }\end{array}$ & 4.34 & 0.880 & 0.824 & & \\
\hline Tourism revives the local economy. & 4.37 & 0.844 & 0.820 & & \\
\hline Tourism increases the income of local population. & 4.34 & 0.890 & 0.801 & & \\
\hline $\begin{array}{l}\text { Tourism increases the life quality of local } \\
\text { population. }\end{array}$ & 4.16 & 0.917 & 0.776 & & \\
\hline Tourism diversifies the local economy. & 4.20 & 0.928 & 0.769 & & \\
\hline $\begin{array}{l}\text { Tourism makes a contribution to the development } \\
\text { of physical infrastructure. }\end{array}$ & 4.12 & 1.047 & 0.698 & & \\
\hline $\begin{array}{l}\text { Tourism helps the protection of historical } \\
\text { monuments. }\end{array}$ & 4.30 & 0.910 & 0.686 & & \\
\hline Tourism supports the development of local crafts. & 4.10 & 0.951 & 0.680 & & \\
\hline $\begin{array}{l}\text { Tourism encourages the local capital based } \\
\text { investment. }\end{array}$ & 3.93 & 0.986 & 0.657 & & \\
\hline
\end{tabular}




\begin{tabular}{|c|c|c|c|c|c|}
\hline Factor & Mean & $\begin{array}{l}\text { Standard } \\
\text { Deviation }\end{array}$ & $\begin{array}{l}\text { Factor } \\
\text { Loading }\end{array}$ & $\begin{array}{l}\text { Cronbach } \\
\text { Alpha }\end{array}$ & $\begin{array}{c}\text { Variance } \\
\text { Explained (\%) }\end{array}$ \\
\hline Tourism helps the protection of natural beauties. & 4.08 & 1.029 & 0.610 & & \\
\hline \multicolumn{4}{|l|}{ Emotional Attitudes Towards Tourism $(n=460)$} & 0.888 & 26.556 \\
\hline $\begin{array}{l}\text { Municipalities should contribute to the tourism } \\
\text { activities through equipment. }\end{array}$ & 3.76 & 1.020 & 0.817 & & \\
\hline $\begin{array}{l}\text { Municipalities should contribute to the tourism } \\
\text { activities through information. }\end{array}$ & 3.99 & 0.897 & 0.769 & & \\
\hline $\begin{array}{l}\text { Municipalities should support the cooperative } \\
\text { tourism activities. }\end{array}$ & 4.01 & 0.988 & 0.767 & & \\
\hline $\begin{array}{l}\text { Municipalities should encourage the citizens to } \\
\text { participate in the tourism activities. }\end{array}$ & 3.86 & 1.012 & 0.761 & & \\
\hline $\begin{array}{l}\text { Municipalities should contribute to the tourism } \\
\text { activities through planning. }\end{array}$ & 4.05 & 0.871 & 0.751 & & \\
\hline $\begin{array}{l}\text { Municipalities should contribute to the tourism } \\
\text { activities through staff. }\end{array}$ & 3.60 & 1.060 & 0.742 & & \\
\hline $\begin{array}{l}\text { Municipalities should support the tourism } \\
\text { oriented commercial partnerships. }\end{array}$ & 3.57 & 1.072 & 0.718 & & \\
\hline \multicolumn{4}{|l|}{ Total Cronbach Alpha / Variance explained (\%) } & 0.927 & 61.109 \\
\hline
\end{tabular}

K-M-O Measure of Sampling Adequacy: 0,909

Bartlett's Test of Sphericity (Sig: 0,000)

As seen in Table 1, in the context of defining the attitudes of mayors towards tourism, for 2 factors belonging to 17 judgments, KMO coefficient (0,909), Bartlett's test for level of significance $(\mathrm{p}=\mathrm{o}, \mathrm{ooo})$, the sum of ratio for variance explanation $(61,109)$, and the sum of reliability coefficients $(0,927)$ are calculated as such. This situation clearly indicates that all requirements for factor analysis are met in this research and the measurement is quite reliable.

Table 2. Factor Analysis for the Rural Tourism Activities of Municipalities

\begin{tabular}{|c|c|c|c|c|c|}
\hline Factor & Mean & $\begin{array}{l}\text { Standard } \\
\text { Deviation }\end{array}$ & $\begin{array}{l}\text { Factor } \\
\text { Loading }\end{array}$ & $\begin{array}{c}\text { Cronbach } \\
\text { Alpha }\end{array}$ & $\begin{array}{c}\text { Variance } \\
\text { Explained (\%) }\end{array}$ \\
\hline \multicolumn{4}{|l|}{ Creation of Social Awareness $(n=460)$} & 0.898 & 19.999 \\
\hline We are organizing art shows. & 2.57 & 1.470160 & .786 & & \\
\hline We are organizing opening days. & 2.82 & 1.465 & .766 & & \\
\hline We are organizing exhibitions and festivities. & 3.02 & 1.572 & .716 & & \\
\hline We are making public meetings. & 2.76 & 1.392 & .700 & & \\
\hline We are periodically publishing bulletins. & 2.85 & 1.407 & .632 & & \\
\hline We are sharing information with the local media. & 3.59 & 1.309 & .587 & & \\
\hline \multicolumn{4}{|l|}{ Organizational Structure Development $(n=460)$} & 0.954 & 19.833 \\
\hline $\begin{array}{l}\text { We are making cooperation to supervise the } \\
\text { visions, goals, and objectives for the development } \\
\text { of our region. }\end{array}$ & 3.73 & 1.166 & .819 & & \\
\hline $\begin{array}{l}\text { We are making cooperation to efficiently } \\
\text { manage the visions, goals, and objectives for the } \\
\text { development of our region. }\end{array}$ & 3.73 & 1.171 & .776 & & \\
\hline $\begin{array}{l}\text { We are making cooperation to prepare educational } \\
\text { programs for the development of our region. }\end{array}$ & 3.88 & 1.187 & .774 & & \\
\hline
\end{tabular}




\begin{tabular}{|c|c|c|c|c|c|}
\hline Factor & Mean & $\begin{array}{l}\text { Standard } \\
\text { Deviation }\end{array}$ & $\begin{array}{l}\text { Factor } \\
\text { Loading }\end{array}$ & $\begin{array}{l}\text { Cronbach } \\
\text { Alpha }\end{array}$ & $\begin{array}{c}\text { Variance } \\
\text { Explained (\%) }\end{array}$ \\
\hline $\begin{array}{l}\text { We are making cooperation to determine the } \\
\text { priorities for the development of our region. }\end{array}$ & 3.78 & 1.187 & .758 & & \\
\hline $\begin{array}{l}\text { We are making cooperation to determine the } \\
\text { visions, goals, and objectives for the development } \\
\text { of our region. }\end{array}$ & 3.84 & 1.123 & .749 & & \\
\hline $\begin{array}{l}\text { We are making cooperation to market the } \\
\text { economy products of our region. }\end{array}$ & 3.91 & 1.177 & .748 & & \\
\hline $\begin{array}{l}\text { We are making cooperation to develop products } \\
\text { for the improvement of economy in our region. }\end{array}$ & 3.91 & 1.097 & .706 & & \\
\hline $\begin{array}{l}\text { We are making cooperation to improve } \\
\text { relationships with institutions outside our region. }\end{array}$ & 3.87 & 1.171 & .688 & & \\
\hline $\begin{array}{l}\text { We are making cooperation to find financial } \\
\text { support for tourism development in our region. }\end{array}$ & 4.00 & 1.200 & .585 & & \\
\hline \multicolumn{4}{|l|}{ Developing Tourism Products $(\mathrm{n}=193)$} & 0.904 & 12.785 \\
\hline $\begin{array}{l}\text { We are working to develop the handcrafts in our } \\
\text { region. }\end{array}$ & 3.71 & 1.420 & .760 & & \\
\hline $\begin{array}{l}\text { We are participating in the efforts to create a } \\
\text { trademark of our own for our tourism products. }\end{array}$ & 3.53 & 1.517 & .754 & & \\
\hline $\begin{array}{l}\text { We are working towards the types of tourism that } \\
\text { are suitable to our region. }\end{array}$ & 3.45 & 1.580 & .714 & & \\
\hline $\begin{array}{l}\text { We are working to promote the agricultural } \\
\text { products that might come to the fore in the } \\
\text { agricultural tourism of our region. }\end{array}$ & 3.54 & 1.492 & .707 & & \\
\hline $\begin{array}{l}\text { We are working to support the sport activities that } \\
\text { might be done in natural environments in our region. }\end{array}$ & 3.53 & 1.482 & .695 & & \\
\hline $\begin{array}{l}\text { We are participating in the restoration of the } \\
\text { historical houses reflecting the culture of our region. }\end{array}$ & 3.36 & 1.652 & .690 & & \\
\hline $\begin{array}{l}\text { We are working to identify the spots that might be } \\
\text { used to watch the natural beauties in our region. }\end{array}$ & 3.67 & 1.504 & .642 & & \\
\hline $\begin{array}{l}\text { We are providing guides for the daily travels to } \\
\text { towns and villages in our region. }\end{array}$ & 2.94 & 1.636 & .633 & & \\
\hline $\begin{array}{l}\text { We are organizing small scale congresses and } \\
\text { meetings towards tourism products in our region. }\end{array}$ & 3.30 & 1.470 & .621 & & \\
\hline \multicolumn{4}{|l|}{ Marketing Tourism Product $(n=197)$} & 0.858 & 9.515 \\
\hline $\begin{array}{l}\text { We are making market segmentation in } \\
\text { accordance to the features of potential tourists } \\
\text { who might visit our region. }\end{array}$ & 2.79 & 1.329 & .759 & & \\
\hline $\begin{array}{l}\text { We are making market surveys towards the } \\
\text { potential tourists who might visit our region. }\end{array}$ & 3.52 & 1.372 & .727 & & \\
\hline $\begin{array}{l}\text { We are making analyses to determine the strong } \\
\text { and weak aspects as well as the opportunities and } \\
\text { the challenges of the tourism market in our region. }\end{array}$ & 3.44 & 1.426 & .674 & & \\
\hline $\begin{array}{l}\text { We are organizing travel programs to the } \\
\text { promotional spots to introduce the tourism of our } \\
\text { region to various guests such as, but not confined } \\
\text { to, tour operators, press staff, political leaders, etc. }\end{array}$ & 3.06 & 1.547 & .584 & & \\
\hline \multicolumn{4}{|l|}{ Total Cronbach Alpha / Variance explained (\%) } & 0.931 & 62.130 \\
\hline
\end{tabular}

K-M-O Measure of Sampling Adequacy: 0, 881

Bartlett's Test of Sphericity (Sig: 0,000) 
As seen in Table 2, in the context of defining the activities of municipalities towards rural tourism, for 4 factors belonging to 28 judgments, KMO coefficient $(0,881)$, Bartlett's test for level of significance $(\mathrm{p}=\mathrm{o}, \mathrm{ooo})$, the sum of ratio for variance explanation $(62,130)$, and the sum of reliability coefficients $(0,931)$ are calculated as such. This situation clearly indicates that all requirements for factor analysis are met in this research and the measurement is quite reliable.

In Table 3, there are the results of "Correlation Analysis" to measure the relationship between the attitudes of mayors towards tourism (cognitive and emotional) and the activities of municipalities towards rural tourism (creation of social awareness, development of organizational structure, product development, product marketing). In this analysis, while the cognitive and emotional attitudes of mayors towards tourism are defined as independent variables, the activities of the municipalities such as the creation of social awareness, development of organizational structure, product development, and product marketing identified as dependent variables.

In accordance with the data presented in Table 3, there found a correlation at the level of significance of $\mathrm{o,01}$ between the attitudes of mayors (cognitive and emotional) and the activities of municipalities towards tourism (creation of social awareness, development of organizational structure, product development, and product marketing).

Table 3. Indicators of Correlation for the Attitudes of Mayors towards Tourism and the Activities of Municipalities towards Tourism

\begin{tabular}{|c|c|c|c|c|c|c|}
\hline & & 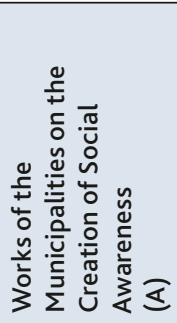 & 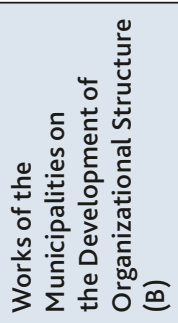 & 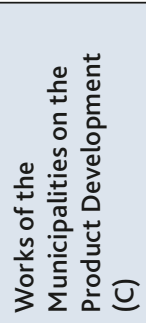 & 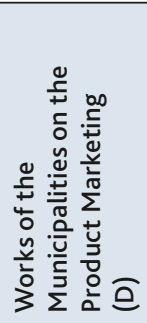 & $\begin{array}{l}0 \\
+ \\
+ \\
+ \\
0 \\
+\end{array}$ \\
\hline \multirow{3}{*}{$\begin{array}{l}\text { Cognitive Attitudes } \\
\text { of the Mayors } \\
\text { towards Tourism }\end{array}$} & Pearson Correlation & $.313^{* *}$ & $.492 * *$ & $.253^{* *}$ & $.354^{* *}$ & $.464^{* *}$ \\
\hline & Sig. (2-tailed) & .000 & .000 & .000 & .000 & .000 \\
\hline & $\mathrm{N}$ & 460 & 460 & 193 & 197 & 460 \\
\hline \multirow{3}{*}{$\begin{array}{c}\text { Emotional Attitudes } \\
\text { of the Mayors } \\
\text { towards Tourism }\end{array}$} & Pearson Correlation & $.481^{* *}$ & $.494 * *$ & $.373^{* *}$ & $.472 * *$ & $.572^{* *}$ \\
\hline & Sig. (2-tailed) & .000 & .000 & .000 & .000 & .000 \\
\hline & $\mathrm{N}$ & 460 & 460 & 193 & 197 & 460 \\
\hline \multirow{3}{*}{$\begin{array}{l}\text { Attitudes of the } \\
\text { Mayors towards } \\
\text { Tourism }\end{array}$} & Pearson Correlation & $.439 * *$ & $.560 * *$ & $.350 * *$ & $.449 * *$ & $.581^{* *}$ \\
\hline & Sig. (2-tailed) & .000 & .000 & .000 & .000 & .000 \\
\hline & $\mathrm{N}$ & 460 & 460 & 193 & 197 & 460 \\
\hline
\end{tabular}

$* *(p<0,001)$

Given the correlation analysis, there is a positive relationship between the attitudes of mayors towards tourism and the activities of municipalities towards tourism. Therefore, attitudes of mayors might be utilized to increase the activities of the municipalities to participate in tourism. In the context of those conclusions, the fundamental and sub hypotheses made in this research are verified following as:

H1: There is a correlation between the attitudes of mayors towards tourism and the tourism activities of municipalities in rural areas.

$\mathrm{H1}_{a}$ : There is a correlation between the cognitive attitudes of mayors and the activities of municipalities to create social awareness about rural tourism. 
$\mathbf{H 1}_{b}$ : There is a correlation between the cognitive attitudes of mayors towards tourism and the activities of municipalities to develop organizational structure in rural tourism.

$\mathrm{H1}_{c}$ : There is a correlation between the cognitive attitudes of mayors and the activities of municipalities to develop products in rural tourism.

H1 $\mathbf{1}_{d}$ : There is a correlation between the cognitive attitudes of mayors and the activities of municipalities to market products in rural tourism.

$\mathrm{H1}_{e}$ : There is a correlation between the emotional attitudes of mayors and the activities of municipalities to create social awareness in rural tourism.

H1: There is a correlation between the emotional attitudes of mayors and the activities of municipalities to develop organization structure in rural tourism.

H1 $\mathbf{g}_{\mathrm{g}}$ There is a correlation between the emotional attitudes of mayors and the activities of municipalities to develop products in rural tourism.

\section{Conclusion}

The research is concentrated on the activities of rural municipalities towards tourism through the attitudes of mayors towards tourism. In this context, by the means of a quantative technique, whether the attitudes of mayors have an impact on the activities of municipalities towards tourism is tested experimentally.

According to the results of the research analysis, the impact of the attitudes of mayors on the activities of rural municipalities towards tourism is important. The data might be useful for the development tourism in rural areas and indicates that mayors might play an efficient role in tourism development in rural areas.

The conclusions of the present study might be utilized to increase the tourism activities in rural areas where tourism is developing at a slow pace and to ensure the participation of the local population, who is not sufficiently informed about tourism, in rural tourism (Sharpley, 2006; Ertuna, et al., 2012). Despite the fact that there are many theoric studies on rural areas and the development of tourism in those areas, there is a limited number of empirical studies to define the theoric studies. Therefore, this study meets the urgent need to conduct case studies by the means of quantative techniques.

Public participation in organizations is of great importance in the achievement of tourism development in rural areas (Verbole, 2000; Tosun, 2001; Tosun, 2006; Briedenhann, 2007; Tao, Fuying, 2009). The realization of these organizations under the leadership of public institutions has further significance in terms of sustainable tourism. Therefore, it is essential that the key role of public leaders be emphasized to enhance their political control over tourism sector (Clark, Chabrel, 2007). In the literature, the strengthening of the staff is approached through "cognitive dimension" and "behavioral dimension" (Spreitzer, 1995; Honold, 1997). In the light of those approaches, social responsibility, local agenda-21, and eco-municipality might be applied to reinforce the mayors at behavioral level. Through those application tools, level of participation of municipalities in tourism might be increased. In case of Turkey, governorships, district governorships, Ministry of Environment and Urbanization, Ministry of Development, Union of Municipalities in Turkey, Ministry of Culture and Tourism, provincial tourism directorates, and universities might be made use of to empower the mayors at cognitive level largely through seminars, conferences, panels, visual and auditory publications, projects, encouragement awards, and technical trips all which are organized by those institutions. 


\section{Limitations}

The research is based on the positive cognitive and emotional attitudes of mayors towards tourism. Therefore, future studies on negative cognitive and emotional attitudes of mayors towards tourism might lead us to new conclusions from a different perspective. Furthermore, the application of scales developed during the research to local government units other than the municipalities might make a contribution to the development of different assumptions.

\section{References}

Ashley, C. 200o. The impacts of tourism on rural livelihoods: Namibia's experience. [Online] $<$ http://www.odi.org.uk/resources/download/2035.pdf> accessed October 29th, 2011.

Ayaz, N. 2012. Rural tourism and its stakeholders: A research on the attitudes of the mayors. Unpublished doctoral dissertation, University of Gazi, Turkey.

Briedenhann, J. 2007. The role of the public sector in rural tourism: Respondents' views. Current Issues in Tourism 10(6), 584-607.

Byrd, E. T., Cardenas, D. A., Dregalla, S. E. 2009. Differences in stakeholder attitudes of tourism development and the natural environment. e-Review of Tourism Research (eRTR) 7(2), 39-51.

Butler, R. W. 1980. The concept of a tourist area cycle of evolution: Implications for management of resources. The Canadian Geographer 24(1), 5-12.

Campanhola. C., Graziano da Silva. J. 1999. Tourism in the rural area as a new opportunity for small farmers. [Online] <http://www.eco.unicamp.br/Downloads/Publicacoes/TextosDiscussao/texto72.pdf $>$ accessed June 7 th, 2011.

Campbell, L. M. 1999. Ecotourism in rural developing communities. Annals of Tourism Research 26(23), 534-553.

Clark, G., Chabrel, M. 2007. Measuring integrated rural tourism. Tourism Geographies, 9(4), 371-386.

Claudia, J., Gürsoy, D. 2004. Distance effects on residents' attitudes toward tourism. Annals of Tourism Research 31(2), 296-312.

European Commission (1999). Towards Quality Rural Tourism. Brussels: Enterprise Directorate General Tourism Unit.

Eraqi, M. 2010. Rural tourism quality: Fayoum as a rural tourist destination in Egypt. International Journal Tourism Anthropology 1(1), 70-86.

Ertuna. B., Güney. S., Güven. Ö., Aydemir. N. 2012. Factors Influencing Residents' Willingness to Participate in Rural Tourism Development: The Case of Kastamonu. International Journal of Social and Economic Sciences 2(2), 59-66.

Farrell, H., Russell, S. 2011. Rural tourism. In P. Robinson, S. Heitmann \& P. Dieke (Eds.). Research Themes for Tourism (pp.10o-113). CAB International: UK.

Garay, L., Cânoves, G., Duro, J. A. 2011. Rural tourism in Spain, from fordism to post-fordism. In M. D. Alvarez, C. A. Genç, B. Hatipoğlu, D. Salman., D. Ünalan (Eds.). Advances in Hospitality and Tourism Marketing and Management Conference Proceedings (pp.553559). İstanbul.

Godfrey, K. B. 1998. Attitudes towards 'sustainable tourism' in the UK: a view from local government. Tourism Management 19(3), 213-224.

Hall. D. 1998. Tourism development and sustainability issues in Central and South-Eastern Europe. Tourism Management 19(5), 423-431. 
Hall, C. M., Jenkins, J. M. 1998. The policy dimensions of rural tourism and recreation. In R.Butler, C. M. Hall, J. M. Jenkins (Eds.). Tourism and Recreation in Rural Areas (pp.28-42). Chichester: Wiley \& Sons.

Hegarty, C., Prezeborska, L. 2005. Rural and agri-tourism as a tool for reorganising rural areas in old and new member states: A comparison study of Ireland and Poland. International Journal of Tourism Research 7(2), 63-77.

Holland, J., Burian, M., Dixey, L. 2003. Tourism in poor rural areas: Diversifying the product and expanding the benefits in rural Uganda and the Czech Republic. Overseas Development Institute, 1-36.

Honold, L. 1997. A review of the literature on employee empowerment. Empowerment in Organizations 5(4), 202-212.

Ishikawa, N., Fukushige, M. 2007. Who expects the municipalities to take the initiative in tourism development? Residents' attitudes of Amami Oshima Island in Japan. Tourism Management (28), 461-475.

Kastenholz, E., Davis, D., Paul, G. 1999. Segmenting tourism in rural areas: The case of North and Central Portugal. Journal of Travel Research (37), 353-363.

Kokkranikal, J. J., Baum, T. 2002. Human resources development for tourism in rural communities: A case study of Kerala. Asia Pacific Journal of Tourism Research (7)2, 64-76.

Kotler, P., Gertner, D. 2002. Country as brand, product, and beyond: A place marketing and brand management perspective. Brand Management 9(4-5). 249-265.

Latkova, P. 2008. An examination of factors predicting residents' support for tourism development. Unpublished doctoral dissertation, University of Michigan State, U.S.

Lesley, R., Hall, D. 2001. Rural Tourism and Recreation: Principles and Practice. Cambridge: CABI Publishing.

Leslie, D., Hughes, G. 1997. Agenda 21, local authorities and tourism in the UK. Managing Leisure 2(3), 143-154.

Lewis, J. 1998. The development of rural tourism. Parks and Recreation 33(9), 99-105.

Long, P. T., Perdue, R. R., Allen, L. 199o. Rural resident tourism perceptions and attitudes by community level of tourism. Journal of Travel Research 28(3), 3-9.

Long, P., Lane, B. 200o. Rural tourism development. In W. C. Gartner., D. W. Lime (Eds.). Trends in Outdoor Recreation Leisure and Tourism (pp.299-308). Wallingford: CABI Publishing.

Middleton, V. T. C., Hawkins, R. 1998. Sustainable Tourism: A Marketing Perspective. London: Butterworth-Heinemann.

Mitchell, M., Derek, H. 2005. Rural tourism and sustainable business: Key themes and issues. In H. Derek, I. Kirkpatrick., M. Mitchell (Eds.). Rural Tourism and Sustainable Business (pp.3-12). Clevedon-Buffalo-Toronto: Channel View Publications.

Momsen, J. H. (200o). Rural tourism. In J. Jafari (Ed.). Encyclopedia of Tourism (pp.514- 515). London, GBR: Routledge.

Oppermann, M. 1996. Rural tourism in Southern Germany. Annals of Tourism Research 23(1), 86-102.

Ryan, C. (1995). Researching Tourist Satisfaction Issues, Concepts, Problems. London: Routledge.

Ribeiro, M., Marques, C. 2002. Rural Tourism and the development of less favored areas-between rhetoric and practice. International Journal of Tourism Research (4), 211-220.

Sharpley, R. 200o. Rural tourism and the challenge of tourism diversification: The case of Cyprus. Tourism Management 23, 233-244. 
Sharpley, R. 2006. Travel and Tourism. London-Thousand Oaks-New Delhi: Sage Publications. Sharpley, R., Sharpley, J. 1997. Rural Tourism: An Introduction. London: International Thomson Business Press.

Smith, M. D., Krannich, R. S. 1998. Tourism dependence and resident attitudes. Annals of Tourism Research 25(4), 783-802.

Soykan, F. 2004. Kırsal Alanların Turizm Potansiyelinin Saptanması ve Şirince Köyüne (İzmir) Uygulanması. İzmir: Ege Üniversitesi Edebiyat Fakültesi Yayınları.

Spreitzer, G. M. 1995. Psychology empowerment in the workplace: Dimensions, measurement and validation. Academy of Management Journal 38(5), 1442-1465.

Strömgren, M., Andersson, R. 2010. The usage of safety management tools in Swedish municipalities. Safety Science 48, 288-295.

Stynes, D. J., O'Halloran, C. 1987. Tourism planning. Michigan State University Extension Tourism Educational Materials, [Online] at $<$ http://web1.msue.msu.edu/imp/modtd/3300ooo5. html $>$ accessed October 1oth, 2011.

Tao, L., Fuying, X. 2009. A study on community participation in rural tourism based on stakeholder theory. [Online] <http://www.seiofbluemountain.com/upload/product/200910/2009glhy14a9.pdf $>$ accessed June 7th 2010.

Tchetchik, A., Fleischer, A., Finkelshtain, I. 2006. Rural tourism: development public intervention and lessons from the Israeli experience. Hebrew University of Jerusalem Department of Agricultural Economics and Management, Discussion Paper, 1-42.

Tchetchik, A., Fleischer, A., Finkelshtain, I. 2008. Differentiation and synergies in rural tourism: Estimation and simulation of the Israeli market. American Journal of Agricultural Economics 90, 553-570.

Timur, S., Getz, D. 2008. A network perspective on managing stakeholders for sustainable urban tourism. International Journal of Contemporary Hospitality Management 2o(4). 445-461.

Tosun, C. 2001. Challenges of sustainable tourism development in the developing world: The case of Turkey. Tourism Management 22, 289-303.

Tosun, C. Timothy, D. J., Öztürk, Y. 2003. Tourism growth, national development and regional inequality in Turkey. Journal of Sustainable Tourism 11, 133-161.

Tosun, C. 2006. Expected nature of community participation in tourism development. Tourism Management 27, 493-504.

United Nations 2007. Report of the World Tourism Organization to the United Nations Secretary-General in preparation for the High Level Meeting on the Mid-Term Comprehensive Global Review of the Programme of Action for the Least Developed Countries for the Decade 2001-2010. [Online] <http://www.un.org/special-rep/ohrlls/ldc/MTR/WorldTourisminput.pdf $>$ accessed June 7 th 2010.

UNWTO 2013. Tourism Highlights, 2013 Edition. [Online] Retrieved, from Web: <http://mkt. unwto.org/publication/unwto-tourism-highlights-2013-edition > accessed January 27, 2014.

Verbole, A. 200o. Actors, discourses and interfaces of rural tourism development at the local community level in Slovenia: Social and political dimensions of the rural tourism development process. Journal of Sustainable Tourism 8(6), 479-490.

Wang, Y. A., Pfister, R. E. 2008. Residents' attitudes toward tourism and perceived personal benefits in a rural community. Journal of Travel Research 47, 84-93.

Wilson, S., Fesenmaier, D. R., Fesenmaier, J., van Es J. C. 2001. Factors for success in rural tourism development. Journal of Travel Research 40, 132-138.

Woods, M. 200o. Diversifying the Rural Economy: Tourism Development. Southern Rural Development Center, 10, June, 1-10. 
Yüksel, F., Yüksel, A. 2008. Perceived clientelism: Effects on residents' evaluation of municipal services and their intentions for participation in tourism development projects. Journal of Hospitality and Tourism Research 32(2), 187-208.

Zecevic, B. 2011. An analysis of the inclusion of tourism in local development strategies. [Online] <http://rs.one.un.org/organizations/12/Local_strategies_and_tourism_Zecevic_ FINAL_ENG.pdf > accessed January 3rd, 2014. 